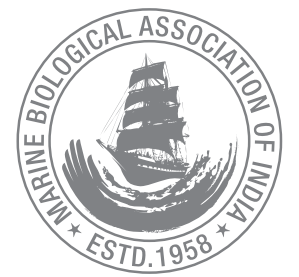

\title{
Socio-economic analysis of finfish culture in cages in coastal waters of Kerala, southwest coast of India
}

\author{
K. C. Vineetha Valsalan*1, V. Kripa, Shelton Padua, R. Narayanakumar ${ }^{2}$ and P. Vysakhan \\ *ICAR-Central Marine Fisheries Research Institute, Kochi - 682 018, Kerala, India. \\ ${ }^{1}$ Cochin University of Science and Technology, Kalamassery, Kochi-22, Kerala, India. \\ ${ }^{2}$ Research Centre of ICAR-Central Marine Fisheries Research Institute, Chennai-28, Tamil Nadu, India. \\ *Correspondence e-mail: vineetha.valsalan@gmail.com
}

Received: 26 Oct 2019 Accepted: 15 May 2020 Published: 20 May 2020

Original Article

\begin{abstract}
Cage culture of finfish is becoming a popular alternate source of livelihood in Vembanad Lake in Kerala, India. A study was conducted during November to December, 2016 to assess the socio-economic status of the farmers practicing cage culture in Kerala and the resultant economic benefits. Data on demographic features, farming activities, specific culture and farm management practices, economics and problems related to cage farming were collected from 36 active farmers of the Ernakulam District. Etroplus suratensis (Pearl spot), Lates calcarifer (Asian sea bass), and Genetically Improved Farm Tilapia (GIFT) were the major species cultured. Among the farmers practicing cage culture, 94.5 per cent of ownership was by males, but female participation $(56 \%)$ in managing the cage was almost equal to that of males (44\%) and all respondents were literate. High growth rate of $L$. calcarifer and the higher market price of $E$. suratensis made these as the most preferred species for farming. Economic efficiency of the two systems i.e., cage stocked with $E$. suratensis (CE) and the cage stocked with L. calcarifer (CL) was compared using the economic indicators such as net profit, rate of return, un-discounted benefit to cost $(B: C)$ ratio and pay-back period. Even though the net profit was more for $\mathrm{CL}$, undiscounted $\mathrm{B}: \mathrm{C}$ ratio was same for both systems ( $C E=3.38$ and $\mathrm{CL}=3.39$ ).
\end{abstract}

Keywords: Cage culture, Vembanad Lake, economic efficiency, mariculture

\section{Introduction}

Cage aquaculture, since its origin has received wide acclaim as a source of livelihood among the coastal fish farmers. The easy management practices and the production of high-quality fishes by utilising the existing water bodies make this the most preferred among the varied fish culture practices (Beveridge, 1996). India, blessed with a coastline of $7517 \mathrm{Km}$ and several fertile estuaries has high potential for cage culture. In India, the first experimental cage made of High Density Poly Ethylene (HDPE) with a diameter of $15 \mathrm{~m}$ was installed at Visakhapatnam in the year 2007 (Rao, 2009). Since then, several innovations were made on the design, fabrication and the mooring systems of the cages which in turn improved their utility in diverse habitats. Though in the beginning, cage culture was not much accepted and appreciated by the fish farmers, the ease of fish culture in cages and the higher monetary returns from these have attracted more farmers to this culture practice. ICAR-CMFRI has played a major role in developing cage culture in the country using different species in different environments, thereby increasing the life standards of the coastal 
community (Mojjada et al., 2012a, 2012b, 2013; Philipose et al., 2013; Ghosh et al., 2016; Joseph and Gopalakrishnan, 2017).

Finfish farming in cages has now developed as an additional source of livelihood for fishers and other coastal villagers. Presently, Rachycentron canadum (Cobia), Trachinotus blochii (Silver pompano), Etroplus suratensis (Pearl spot), Lates calcarifer (Sea bass), Genetically Improved Farm Tilapia (GIFT), Lutjanussp. (Red snapper) and Mugil cephalus (Grey mullet) are the most common farmed fin fish species in cages. Various research institutes like ICAR-Central Marine Fisheries Research Institute (CMFRI), Marine Products Export Development Authority (MPEDA), ICAR-Central Institute of Brackishwater Aquaculture (CIBA), ICAR-Central Institute of Freshwater Aquaculture (CIFA), ICAR-Central Inland Fisheries Research Institute (CIFRI) and related organizations are providing training and technical support to the stakeholders for promoting this aquaculture activity among the coastal community. Apart from the technical inputs, the state department, local governing bodies and $\mathrm{NGOs}$ also provide financial assistance to the farmers to adopt the cage culture. In addition to the direct beneficiaries, such as the fish farmers, cage culture has provided alternative livelihood to several villagers who are engaged in supply of seed, feed and raw materials for designing the cage.
There are also technically skilled fish cage designing villagers in Kerala, who provide their services on payment.

Currently along the west coast, participatory cage culture is practiced widely in coastal states like Kerala, Karnataka and Goa. In Kerala, cages are installed primarily in the Vembanad Lake which is $2033.02 \mathrm{~km}^{2}$ in area. The present study focuses on the cage culture systems in the Vembanad Lake and their impacts on the socio-economic upliftment of the stakeholders. Eventhough, there have been several studies focussing on the economic aspects of various aquaculture activities in India, there are only a few studies on the socio-economic status of the fish farmers practicing cage culture.

\section{Material and methods}

The primary data for the present study was collected through personal interview with a pre-tested interview schedule. The data included personal details of the farmers, the farming activities, specific farm management practices, economics and the problems related to cage farming. The survey covered 36 active farmers from Pizhala, Nettoor, Moolampilli, Njarackal and Poothotta in Vembanad Lake (Fig. 1).

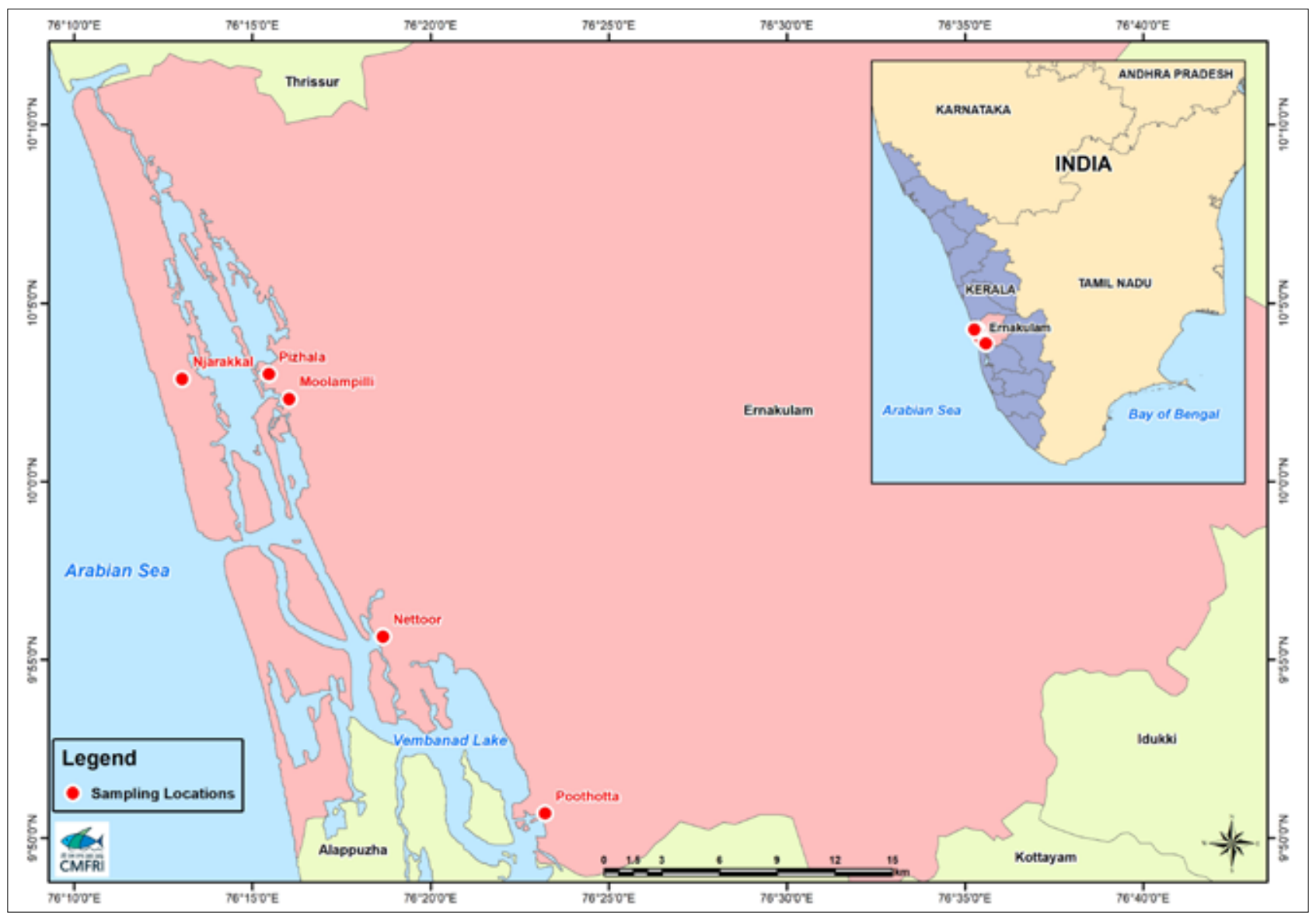

Fig.1. Map of Vembanad Lake, south-west coast of India showing the study area 
To assess the socio-economic status of the farmers, information related to the age, gender, education, occupation, family size and status were collected. Besides the details on the species cultured and stocking density, type of culture, procurement of seed and feed, material and size of the cage, maintenance of the cage and experience in farming were also collected.

For the economic analysis of the culture system, fixed costs, operating/variable costs, gross revenue, annual profit, rate of return and payback period of the culture system were worked out. The total cost comprised the sum of the yearly fixed cost and the yearly operating cost. The operating cost, also called as variable cost formed the cost incurred when the farm was under operation and included the costs of seed and feed, maintenance and medication costs if any and the transportation cost. Fixed cost is the cost incurred even if the farm is not operating and included the interest on capital investment, insurance for the capital investment and the depreciation on the permanent assets. Depreciation was calculated on the basis of the life expectancy of each item in the capital investment $(12.5 \%$ for frame and floaters, $33.33 \%$ for net and $50 \%$ for bamboo poles/anchor). The economic feasibility and efficiency of the culture practice was also assessed using the equations:

$\mathrm{TC}=\mathrm{AFC}+\mathrm{AOC}$

$\mathrm{NP}=\mathrm{GR}-\mathrm{TC}$

Undiscounted $B: C$ ratio (undiscounted value

of benefits $\div$ undiscounted value of costs)

$\mathrm{RR}=(\mathrm{NP} / \mathrm{Cl}) \times 100$,

where, $\mathrm{TC}=$ Total cost, $\mathrm{AFC}=$ Annual fixed cost, $\mathrm{AOC}=$ Annual operating cost, $\mathrm{NP}=$ net profit, $\mathrm{GR}=$ Gross revenue, $\mathrm{B}=$ Benefit, $\mathrm{C}=$ Cost, $\mathrm{RR}=$ Rate of return, $\mathrm{Cl}=$ Capital investment

Payback period is the time required to recover the initial investment outlay on the project. According to the payback criterion, the shorter the payback period, the more desirable is the project. It was estimated using the formula

$\mathrm{P}=\mathrm{C} / \mathrm{E}$

where, $\mathrm{P}=$ Payback period of the project, $\mathrm{C}=$ Capital investment of the project in Rupees (INR) and $E=$ Annual net profit in Rupees (INR).
Statistical techniques such as frequency distribution and mean were used to analyse the data.

\section{Results and discussion}

\section{General aspects}

\section{Socio economic characteristics}

The information generated from the survey indicated that, $83.33 \%$ of farmers involved in finfish farming were middle aged (35-50 years) while $11.11 \%$ were youngsters (age $<35$ years) and $5.55 \%$ were of the age above 50 years (Table 1). The literacy rate among the cage culture farmers was $100 \%$ which is higher than the average literacy rate $(96.65 \%)$ reported for the Ernakulam District (Census, 2011). Of the literate farmers, $80.55 \%$ have studied up to secondary level (Table 1). Studies conducted on this aspect have reported on the influence of literacy on the increased innovations of culture practices among the farmers (Zanu et al., 2012). When considering the farm ownership, it was observed that, out of the total farms, $94.5 \%$ of the owners were men and the rest $5.5 \%$ were women. But the percentage of participation of females and children in the operation of the farm was found to be more (Table 2). Joseph (2016) has reported that, women in Pizhala area were more involved in managing the cages than the male members of the family.

Occupational background of $63.89 \%$ of the stakeholders were doing either fishing or shrimp farming and the rest $36.11 \%$

\begin{tabular}{|c|c|c|}
\hline Category & & Percentage (\%) \\
\hline \multirow[t]{3}{*}{ Age (years) } & $<35$ & 11.11 \\
\hline & $35-50$ & 83.33 \\
\hline & $>50$ & 5.56 \\
\hline \multirow[t]{2}{*}{ Gender } & Female & 5.5 \\
\hline & Male & 94.5 \\
\hline \multirow[t]{3}{*}{ Education } & Secondary & 63.89 \\
\hline & Upper Primary & 36.11 \\
\hline & Lower Primary & 0 \\
\hline
\end{tabular}

Table 2. Occupation pattern of family members involved in cage farm

\begin{tabular}{llll}
\hline Activity & $\begin{array}{l}\text { Women and } \\
\text { Children alone }\end{array}$ & Men alone & $\begin{array}{l}\text { Men and women } \\
\text { jointly }\end{array}$ \\
\hline Seed stocking & 0 & 66.7 & 33.3 \\
\hline Feeding & 55.6 & 0 & 44.4 \\
\hline Maintenance of cage & 0 & 52.8 & 47.2 \\
\hline Harvest & 0 & 0 & 100 \\
\hline Marketing & 0 & 0 & 100 \\
\hline
\end{tabular}


were involved in other professions such as carpentry, black smith and agriculture. But as all these farmers hailed from the coastal area, they were familiar with fishing and related activities. Most of the respondents (91.66\%) lived as nuclear family of 4 to 5 members.

\section{Farming aspects}

The survey indicated that, the finfish species preferred by the different farmers included E. suratensis (pearl spot), GIFT (tilapia), L. calcarifer (sea bass), Lutjanus sp (red snapper), R. canadum (cobia) and M. cephalus (grey mullet). Pearl spot formed the

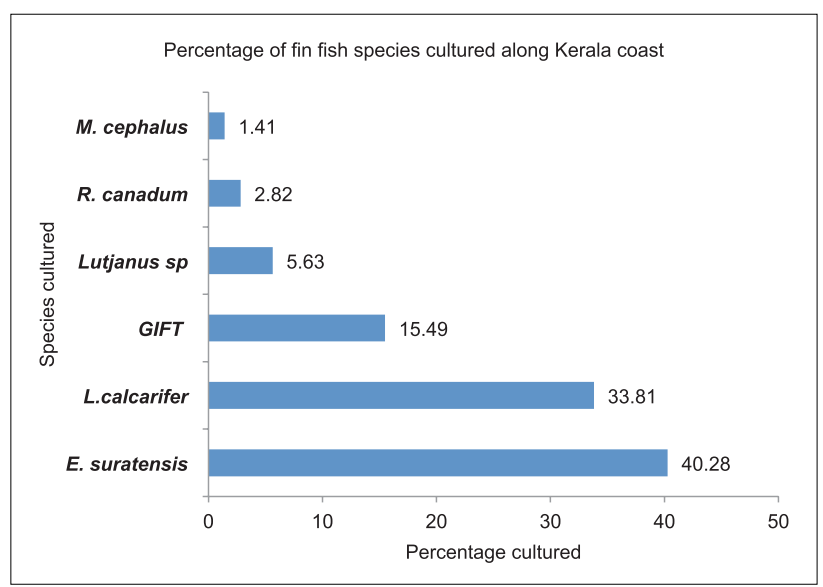

Fig. 2. Percentage of different finfish species farmed in cages in Vembanad Lake

most commonly cultured fish $(40.28 \%)$, followed by sea bass (33.81\%), GIFT (15.49\%), red snapper (5.63\%), cobia (2.82\%) and mullet (1.41\%). (Fig. 2).

All the farmers used galvanised iron (GI) for the frame construction of the cage and provided floatation using plastic barrels. About $94.5 \%$ of the cages surveyed were of size $4 \times 4 \mathrm{~m}$ and were installed in areas where the depth was 2.5 to $3 \mathrm{~m}$. Stocking density in the cage varied with different cages, but a maximum of 500 fingerlings of $3-5 \mathrm{~cm}$ length were stocked in most of the cages irrespective of the species. The seed was sourced from local suppliers. Out of the 36 farmers, one farmer from Pizhala collected naturally produced seed of pearl spot from the nearby

Table 3. Experience of stakeholders in Aquaculture

\begin{tabular}{lll}
\hline Experience & Number & Percentage \\
\hline Less than 5 years & 16 & 44.44 \\
\hline $5-10$ years & 12 & 33.33 \\
\hline $10-15$ years & 5 & 13.88 \\
\hline More than 15 years & 3 & 8.33
\end{tabular}

areas. He also maintained a nursery and some farmers in the Pizhala region procured the seeds of pearl spot from him.

The feed preferences also varied as per the species cultured. In the initial stages, all the species were fed with pellet feed. Later, carnivorous fishes were fed with trash fish in addition to pellets. Some farmers preferred feeding the farmed stock with trash fish alone as it was easily available. For other fishes, pellet feed alone was given. Cost of feed depended on the type of feed used. Trash fish was relatively cheap $\left(10-15 \mathrm{Kg}^{-1}\right)$ whereas for the pellet feed, the price ranged from $32-42 \mathrm{Kg}^{-1}$. For carnivorous fish, $500 \mathrm{Kg}$ trash fish was used while for others, $240 \mathrm{Kg}$ pellet feed was used per crop of 8 months period.

Analysis of the experience of the farmers in the field of aquaculture indicated that, $44.44 \%$ among the respondents had less than five years of experience. $33.33 \%$ had five to ten years of experience, $13.88 \%$ had $10-15$ years of experience while only $8.33 \%$ had more than 15 years of experience.

\section{Economic analysis}

\section{Capital investment and annual fixed cost}

Agricultural economists define capital as the monetary representation of the physical inputs used in agricultural production, in addition to financial assets (Nathanael, 2002). Eventhough Huguein (1997) has reported that, economic analysis is not sensitive to the initial costs of installation of the

Table 4. Capital investment and annual fixed cost for cage farming of Sea bass (CL) and Pearl spot (CE)

\begin{tabular}{ll}
\hline Particulars & $\begin{array}{l}\text { Cost for fish cage of size 4x4m CE and } \\
\text { CL (Rupees, INR) }\end{array}$ \\
\hline Capital Investment & $18000(40 \%)$ \\
\hline Gl cage & $15000(33.33 \%)$ \\
\hline Net & $6000(13.33 \%)$ \\
\hline Bamboo Poles & $4000(8.90 \%)$ \\
\hline Floats & $2000(4.44 \%)$ \\
\hline Others & 45000 \\
\hline Total & \\
\hline Annual fixed cost & 4500 \\
\hline Interest (10\% per annum) & 900 \\
\hline Insurance (2\%) & 17150 \\
\hline Depreciation & 2250 \\
\hline Gl cage (12.5\% per annum) & 5000 \\
\hline b) Net (33.33\% per annum) & 3000 \\
\hline Bamboo Poles (50\% per annum) & 500 \\
\hline Floats (12.5\% per annum) & 1000 \\
\hline Others (50\% per annum) & \\
\hline
\end{tabular}


culture system, in the present study, initial investment was also considered for the economic analysis, as the interest on initial investment was $26.24 \%$ of the annual fixed cost. Here in the case of cage culture, the funds invested for the installation of cage, the major and minor accessories involved in the cage culture comprise the capital investment. As per the survey, the initial investment/capital investment $(\mathrm{Cl})$ for setting up of the cage was estimated to be 45000 comprising the cost of the $\mathrm{Gl}$ pipe/frame $(40 \%)$, net $(33.33 \%)$, anchoring system (13.33\%) floats (8.90\%) and others (4.44\%) (Table 4.). The use of low cost materials in the fabrication of cages and anchoring system ensures a lower investment for the installation of marine fish farming systems (Nhu et al., 2011). The annual fixed cost (FC) was found to be 17,150 , contributed by the interest on the capital investment $(26.24 \%)$, insurance for the capital investment (5.25\%) and the depreciation amount (68.51\%). For the present analysis, the cages stocked with $E$. suratensis (CE) and the cages stocked with L. calcarifer (CL) were selected (hereafter represented as $\mathrm{CE}$ and $\mathrm{CL}$ ).

\section{Annual operational cost}

Operating cost (OC) (Table 5) varied for different species depending on the cost for the seed and feed. For $E$. suratensis farming, the cost of feed was higher $(69.23 \%)$ compared to the cost of seed $(23.08 \%$.) whereas in L. calcarifer farming, cost of seed $(67.92 \%)$ was more than that of the feed $(28.30 \%)$. Hence, it can be stated that, the total cost for $E$. suratensis farming is less (₹30150) compared to that of sea bass (₹43650).

Of the two systems considered ( $\mathrm{CE}$ and $\mathrm{CL}$ ), $\mathrm{CE}$ exhibited higher $(90 \%)$ survival rate compared to that of $\mathrm{CL}(80 \%)$ (Table 6). The profit or loss of an aquaculture system depends on the survival of the animal throughout the production cycle thereby ultimately affecting productivity (Kam et al., 2003). The growth rate of L. calcarifer was higher as it attained $1200 \mathrm{~g}$ weight on an

Table 5. Annual operating cost for pearl spot and sea bass farming in a cage of $4 \times 4$ $\mathrm{m}$ size with stocking density of 500 seeds

\begin{tabular}{lll}
\hline Particulars & Pearl spot farming (INR) & Sea bass farming (INR) \\
\hline Seed & 3000 & 18000 \\
\hline Feed & 9000 & 7500 \\
\hline Maintenance & 1000 & 1000 \\
\hline Total & 13000 & 26500 \\
\hline
\end{tabular}

Table 6. Total production from the cages stocked with $E$. suratensis (CE) and $L$. calcarifer (CL) for a period of eight months

\begin{tabular}{lllllll}
\hline Species & $\begin{array}{l}\text { Seeds } \\
\text { (No.) }\end{array}$ & $\begin{array}{l}\text { Total } \\
\text { survival } \\
\text { (No.) }\end{array}$ & $\begin{array}{l}\text { Average } \\
\text { individual } \\
\text { weight at } \\
\text { harvest }(\mathrm{g})\end{array}$ & $\begin{array}{l}\text { Total } \\
\text { production } \\
(\mathrm{Kg})\end{array}$ & $\begin{array}{l}\text { Unit } \\
\text { price } \\
(\square / \mathrm{Kg})\end{array}$ & $\begin{array}{l}\text { Gross } \\
\text { returns } \\
(\square)\end{array}$ \\
\hline E. suratensis(CE) & 500 & 450 & 550 & 247.5 & 400 & 99,000 \\
\hline L. calcarifer $(\mathrm{CL})$ & 500 & 400 & 1200 & 480 & 300 & $1,44,000$ \\
\hline
\end{tabular}

average in eight months duration while $E$. suratensis attained $550 \mathrm{~g}$ weight on an average in the same period. The market price of $E$. suratensis was relatively higher and fetched ₹ $400 \mathrm{Kg}$ ${ }^{1}$ compared to that of ₹300 $\mathrm{Kg}^{-1}$ for L. calcarifer. High growth rate of $L$. calcarifer resulted in higher gross returns (Table 6).

\section{Profitability}

In the present study, comparison of the net profits (Table 7) from two systems ( $C E$ and $\mathrm{CL}$ ) indicates that, $\mathrm{CL}$ is more profitable than $C E$, eventhough the operating cost is more. Both the systems had high rates of return and very low payback period. Payback period was only seven months for CE and five months

Table 7. Economic indicators of culture systems

\begin{tabular}{lll}
\hline Indicator & $\mathrm{CE}$ & $\mathrm{CL}$ \\
\hline Net profit (Rs lakhs) & 0.69 & 1.00 \\
\hline Undiscounted B:C ratio & 3.28 & 3.30 \\
\hline Rate of return (\%) & 153 & 223 \\
\hline Payback period (Year) & 0.65 & 0.45 \\
\hline
\end{tabular}

for $\mathrm{CL}$. The rates of return were more than $100(155 \%)$ for CE and more than $200(225 \%)$ for CL. The undiscounted benefit to cost ratio for CE was 3.38 and 3.39 for $\mathrm{CL}$. An investment is found to be profitable, if the benefit to cost ratio is greater than 1 (Oladejo and Ofoezie, 2006). These results showed the high economic efficiency of both the culture systems.

\section{Innovations}

Among the 36 farmers practicing cage culture in Cochin estuary, some of them have introduced various innovations in the structure of farm and the method of farming activities to make cage culture more economical. In the economical analysis done in the study, the cost that reduced through these innovations are not considered. An innovation is an idea, practice or project that is perceived as new by an individual or other unit of adoption (Rogers, 2003). The farmers of Pizhala region have started introducing $E$. suratensis prior to the seeding of the major farmed fish species as a new innovative practice in cage culture. E. suratensis seeds are introduced into the cages and allowed to grow along with the major farmed fish species as a step to reduce the biofouling in the cages. Padmakumar et al. (2009) have reported that, algal growth and net clogging is almost absent in cages stocked with pearl spot. The introduction of this pearl spot species has brought dual benefit to the farmers as $E$. suratensis fetches good market price along with reducing biofouling of cages. Another method adopted by some farmers were the stocking of about 2500 seeds of $E$. suratensis were introduced into one $4 \times 4$ cage and were eventually segregated after one month and about 600-700 numbers were stocked separately in different cages. This ensured 
uniform size of the fish at the time of harvest. In addition, instead of the $4 \times 4 \mathrm{~m}$ sized cages, farmers have now started using $8 \times 4 \mathrm{~m}$ sized cages to decrease the number of floats and to reduce the investment in the cage framing by ₹1000.

The present study brought about the inference that cage culture of finfishes is an economical and profitable agricultural model, with payback period of less than a year. The farmers could reduce their fixed cost and increase bottom line by using GI pipes for frame construction. E. suratensis and L. calcariferwere the most preferred finfish species for cage culture practices as it earned them maximum return. The study reveals that most of the cages were owned by men however, there were active participation of both the genders in the management of farms ( $56 \%$ of female and $44 \%$ of male).

The study concludes that cage farming in the Vembanad Lake is a viable proposition for livelihood. The additional income generated through cage farming will help in the socio- economic upliftment of fishermen community of this region.

\section{Acknowledgements}

The authors would like to thank the Director, ICAR-CMFRI for providing an opportunity to conduct this work. The authors are obliged to all the staff and scholars of Fishery Environment Management Division, ICAR-CMFRI, Kochi for all the support rendered during the conduct of this work. We also thank Cochin University of Science and Technology for providing the opportunity to work in this project. The University Grants Commission, New Delhi is also greatly acknowledged for providing financial assistance. The authors are also grateful to the fish cage farmers for providing all the assistance and cooperation extended during the conduct of this work.

\section{References}

Beveridge, M.C.M. 1996. Cage Aquaculture. Blackwell Publishers, Oxford, 368 pp. Census of India. 2011. Kerala series-33 part XII-A, District census handbook, Ernakulam - village and town directory, Directorate of census operations, Kerala, 68-71p.

Ghosh, S., S. Megarajan, R. Ranjan, B. Dash, P. Patnaik, L. Edward and B. Xavier. 2016. Growth performance of Asian seabass Lates calcarifer (Bloch,1790) stocked at varying densities in floating cages in Godavari Estuary, Andhra Pradesh, India. Indian J. Fish., 63(3): 146-149.

Huguenin J. E. 1997. The design, operations and economics of cage culture systems. Aquacult. Eng., 16: 167-203.

Joseph, I. 2016. Transforming rural livelihood through cage farming. Mar. Fish. Infor. Serv., T\& E Ser., No.230. 10-12 p.

Joseph, I. and A. Gopalakrishnan. 2017. Cage farming headed for equal opportunity in aquaculture development in Kerala, India. Asian Fish. Sci., special issue 30S: 387-391.

Kam, L. E., P. S. Leung and A. C. Ostrowski. 2003. Economics of offshore aquaculture of Pacific threadfin (Polydactylus sexfilis) in Hawaii. Aquaculture, 223: $63-87$.

Mojjada S. K., Imelda Joseph, Mohammed Koya, K. R. Sreenath, Dash Gyanaranjan, Sen Swatipriyanka, D. F. Mahendra, M. Anbarasu, H. M. Bhint, S. Pradeep, P. Shiju and G. S. Rao. 2012a. Capture based aquaculture of mud spiny lobster, Panulirus polyphagus (Herbst 1793) in open sea floating net cages off Veraval, north-west coast of India. Indian J. Fish., 59(4): 29-34.

Mojjada S. K., Imelda Joseph, G. Maheswarudu, R. Ranjan, S. Ghosh and G. S. Rao. 2012b. Open sea mariculture of Asian seabass Lates calcarifer (Bloch, 1790) in marine floating cage at Balasore, Odisha, north-east coast of India. Indian J. Fish., 59(3): 89-93.

Mojjada, S. K., Imelda Joseph, P. S. Rao, C. K. Mukharjee, S. Gosh and G. S. Rao. 2013. Design, development and construction of open sea floating cage device for breeding and farming marine fish in Indian waters. Indian J. Fish., 60(1): 61-65.

Nathanael, H. and P. Manning. 2002. Promotion of sustainable commercial aquaculture in Sub-Saharan Africa - Volume 2: investment and economic feasibility. FAO fisheries technical paper 408/2.

Nhu, V. C., Q. H. Nguyen, T. L. Le, M. T. Tran, P. Sorgeloos, K. Dierckens, H. Reinertsen, E. Kjorsvik and N. Svennevig. 2011. Cobia Rachycentron canadum aquaculture in Vietnam: recent developments and prospects. Aquaculture, 315: $20-25$.

Oladejo, S. O. and I. E. Ofoezie. 2006. Unabated schistosomiasis transmission in Erinle River Dam, Osun State, Nigeria: evidence of neglect of environmental effects of development projects. Trop. Med. Int. Health, 11(6): 843-850.

Padmakumar, K. G., P. S. Manu and L. Bindu. 2009. Open Water Farming of Pearlspot Etroplus suratensis (Bloch) in Low-Volume Cages. Asian Fish. Sci., 22: 839-847.

Philipose, K. K., J. Loka, S. R. Krupesha Sharma, D. Divu, S. K. Rao, N. Sadhu, P. Dube, G. Gopakumar and G. S. Rao., 2013. Farming of cobia, Rachycentron canadum (Linnaeus 1766) in open sea floating cages in India. Indian J. Fish., 60(4): 35-40.

Rao, G. S. 2009. Marine cage farming in India recent initiatives. Infish souvenir., 48-51p.

Rogers, E. M. 2003. Diffusion of innovations, $5^{\text {th }}$ edition. New York Free Press. 12pp.

Zanu, H. K., A. Antiwiwaa and C. T. Agyemang. 2012. Factors influencing technology among pig farmers in Ashanti Region of Ghana. J. Agri. Tech., 8(1): 81-92. https:// www.investopedia.com/terms/c/capital-investment.asp 